\title{
RABAUT-POMMIER, A NEGLECTED PRECURSOR OF JENNER
}

\author{
by
}

\section{JEAN THÉODORIDÈS*}

IN HER recent article on the history of smallpox, Lise Wilkinson recalls some observations on preventive transmission of cowpox to man made before Jenner. ${ }^{1}$ Among the names mentioned it is surprising not to find that of Jacques-Antoine Rabaut-Pommier (1744-1820), a French protestant pastor born in Nîmes and living near Montpellier.

Concerning Rabaut-Pommier, Beaulieu recalls (English translation): “About 1780 he had observed in the environs of Montpellier the fact that smallpox, sheep scabs, and cow blotches were regarded as identical diseases known by the name of pox. He noticed that the affection was least serious in cows and that when, by chance, the peasants had contracted it in milking the animals, they could go through the country, protected from smallpox by this alone. So he concluded this procedure to be as certain as 'inoculation' for smallpox and less dangerous." 2

The important fact is that, through a mutual friend (a Bristol merchant called James Ireland), Rabaut-Pommier met an English physician, Dr. Pugh (or Pew), to whom he communicated his observations. Pugh promised to transmit these to his friend Edward Jenner, who was interested in the same problem.

The outbreak of the French Revolution, in which Rabaut-Pommier and his family played an important part (his brother Rabaut-Saint Etienne, a deputy at the Assemblée Nationale, was beheaded in 1793), prevented him from proceeding with his observations on cowpox. But after the publication of Jenner's book on vaccination (1798) he was surprised not to find in it any reference to his earlier suggestions. Furthermore, he wrote to the Comité Central de Vaccine in 1810 to recall his observations without, however, gaining any support substantiating his claims. ${ }^{3}$

In 1811 James Ireland wrote to Rabaut-Pommier saying that he remembered very well his conversation on cowpox with Dr. Pugh in 1784, but that similar observations had been made in England before. In spite of this lack of support from the French and English doctors, "Rabaut-Pommier ought to have a large part of the glory which this great discovery has brought to the English savant". ${ }^{4}$ All this has been mentioned in J. Hall Stewart's article. ${ }^{5}$

*Jean Théodoridès, D.Sc., D.Litt., 16 Square Port-Royal, 75013 Paris, France.

${ }^{1}$ Lise Wilkinson, 'The development of the virus concept as reflected in corpora of studies on individual pathogens. 5. Smallpox and the evolution of ideas on acute (viral) infections', Med. Hist., 1979, 23: 1-28, see pp. 14-15.

2 Biographie universelle, Paris, 1854, vol. 35, p. 7.

- Armand Lods, 'Rabaut-Pommier, pasteur, inventeur de la vaccine, conventionnel et proscrit, 1744-1820', Bull. Soc. Hist. Protest. Fr., 1893, 42: 169-191.

Ibid.

- John Hall Stewart, 'Rabaut-Pommier and the discovery of vaccine', Amer. Med., 1928, 34: 195-199. 


\section{News, Notes and Queries}

Recently, on the occasion of the 150th anniversary of Jenner's death, a French historian of medicine again recalled the importance of Rabaut-Pommier's observations. ${ }^{6}$ Unfortunately this body of evidence seems to be still little noticed in Jenner's home country.

Lise Wilkinson writes-I am grateful to Dr. Théodoridès for drawing attention to the contribution of Jacques-Antoine Rabaut Pommier. It further emphasizes the point that observations similar to Jenner's were made in several regions where cowpox was endemic on the European continent and in Britain throughout the latter half of the eighteenth century and perhaps even before. Certainly some were made before either Rabaut Pommier or Jenner was ten years old. Jenner's own earliest observations supposedly dated back to the early 1770 s.

If Jenner did in fact receive the corroborative information from Dr. Pugh (or Pew), then Rabaut Pommier could perhaps have expected to see it acknowledged in 1798. However, few authors in the eighteenth or even well into the nineteenth century were very scrupulous about acknowledgements (fascinating studies could be made of influences and suggestions which remained unacknowledged in works published during this period), and the present case seems to have been little more than comparing of notes.

- Philippe Decourt, 'La vie exemplaire et l'oeuvre de Jenner. "Variolisation" et "vaccination" au XVIIIe siècle', Arch. Int. Claude Bernard, 1973, 4: 175-185 (pp. 183-185 are devoted to 'RabautPomier [sic] et sa famille'). 